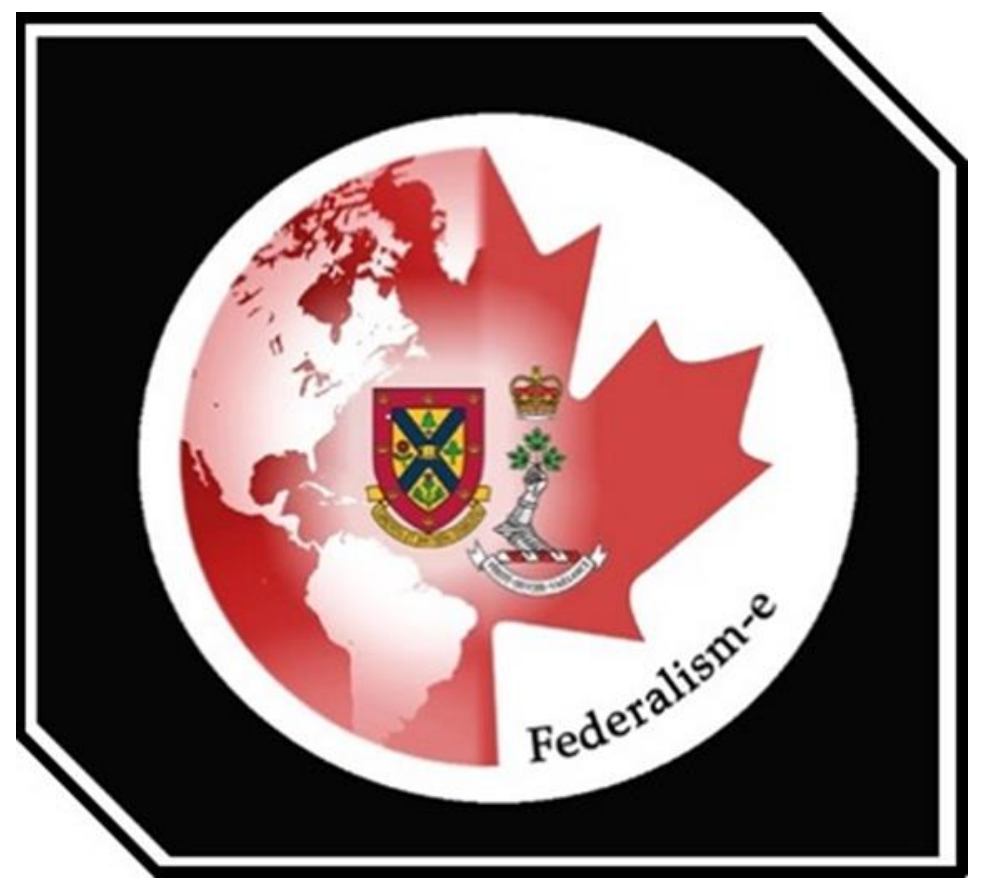

\title{
Federalism-E
}

Tenth Amendment:

The United States' Defining Compromise

By: MIDN 4/C Lucy Ackerman

United States Naval Academy

Federalism-E is founded by the Royal Military College of Canada and the Institute of Intergovernmental Relations at Queen's University

Federalism-E Vol. 20, No.1 (2019) 
Federalism- $E$ is an online, undergraduate student-run journal focusing on the theory of federalism. Federalism-E publishes academic articles and essays focusing on federalism, multi-level governance, and intergovernmental relations. Publishing in both English and French, the journal has a mandate to provide a forum encouraging research and scholarly debate with respect to a wide variety of issues concerning federalism, both within Canada and abroad.

\title{
Editors-in-Chief
}

Officer Cadet Miles Smith, Royal Military College of Canada

Officer Cadet Alexandre Veilleux, Royal Military College of Canada

\author{
Associate Editors: \\ Officer Cadet Jack Wery, Royal Military College of Canada \\ Officer Cadet Jack Murphy, Royal Military College of Canada \\ Officer Cadet Damian McCracken, Royal Military College of Canada \\ Rylee Rose Kloek, University of Ottawa \\ Joyce Le-Yi Yang, University of Toronto \\ Mduduzi Mhlanga, University of Toronto \\ Srijan Sahu, University of Toronto \\ Jenna Mohammed, University of Toronto Mississauga \\ Ali Bachir Taha, University of Toronto \\ Charmaine Lee, University of British Columbia
}

\section{Faculty Advisor:}

Dr. Christian Leuprecht, Royal Military College of Canada, Institute of Intergovernmental

Relations at Queen's University

Contact Information:

Address: Royal Military College of Canada

13 General Crerar Crescent

Kingston

ON, K7K 7B4

ISSN: 2562-3435

Email: federalismeditors@gmail.com

Website: https://ojs.library.queensu.ca/index.php/fede

Federalism-E is founded by the Royal Military College of Canada and the Institute of Intergovernmental Relations at Queen's University

Federalism-E Vol. 20, No.1 (2019) 
The Federalist Papers of 1788 acted as a platform for the founders to express their reasoning for the construction of the Constitution, all with the intention of promoting its ratification. In January 1788, Alexander Hamilton wrote Federalist No. 45, addressing the alleged dangers that a central government would present towards the sovereignty of state governments. In order to calm the fear that the central government would cause the dissipation of state rights, Hamilton indirectly refuted the need for an explicit statement that would hold the central government accountable for the preservation of state rights. Hamilton wrote:

"Were the plan of the convention adverse to the public happiness, my voice would be, Reject the plan. Were the Union itself inconsistent with the public happiness, it would be, Abolish the Union. In like manner, as far as the sovereignty of the States cannot be reconciled to the happiness of the people, the voice of every good citizen must be, Let the former be sacrificed to the latter. How far the sacrifice is necessary, has been shown."'

Hamilton, a founder of the Constitution, believed that sacrifice, in the form of state rights, was a necessity. He believed that sacrifice was fair because the construction of the Constitution ensured the central government to be inclusive and to not overly inhibit state sovereignty, which he buttressed with his argument on checks and balances. ${ }^{2}$ Hamilton was indirectly ignorant of the necessity of the Tenth Amendment, as he did not embody the same fears as the Anti-Federalists. The Anti-Federalists, in the end, disregarded the Federalist Papers and forced the hand of the founders' into a compromise - the Tenth Amendment. The Tenth Amendment originated as a compromise and has been labeled as a Constitutional truism. However, the Supreme Court has significantly developed the relevance and use of the Amendment through two major time periods: the interwar period and the recent 42 years.

The sources cited in this paper fall into three categories: Supreme Court cases, peerreviewed articles, and recently published news articles. The Supreme Court cases allow for the research to be well cemented in accuracy and facts. More so, the Court cases help dictate the structure of the evolutionary section of the paper. The peer-reviewed articles, go beyond the direct facts of the cases to provide both a wide array of analyses and critiques on the Tenth Amendment and its application in court. The three main peer-reviewed articles used in this work: Capital University Law Review 25, Polity 26, and University of Colorado Law Review 57 articulate the Tenth Amendment thoroughly. Together, the three articles address how the interpretation of the Tenth Amendment has developed since its creation. The articles have done so through a variety of cases that have both set and overridden precedents. Finally, three news articles, published respectfully by The Atlantic, Fox News, and The National Law Review provide insight into how the public portrays the Tenth Amendment in modern times, and, therefore, illuminates where the Amendment stands in its development and where it may head.

Born from the fears of the Anti-Federalists and subject to the framers' goal of ratification, the Tenth Amendment was conceived with the intention of protecting the young nation's original core value: state sovereignty. The Anti-Federalists feared the return of what they had fought so hard to break away from -- the tyranny of a central power over the rights of the people.

Therefore, they wanted a law that would hold the country accountable for the preservation of state sovereignty.

\footnotetext{
${ }^{1}$ Federalist, no. 45 (Alexander Hamilton).

${ }^{2}$ Ibid
} 
At the same time, the framers were in need of a compromise to incentivize ratification. They included the Tenth Amendment as a means to ratify the Constitution. As such, the Tenth Amendment was a by-product of political debate about the key value of state sovereignty.

As the American Revolution came to an end, the United States entered the Critical Period. From 1781 to 1789 , the Articles of Confederation ruled the young nation. Although the Articles of Confederation helped to guide the United States during the American Revolution, the Federalists did not believe that the Articles were substantial enough to sustain a growing nation. On February 4, 1787, Shays's Rebellion illustrated the inadequacies of the national government that the Articles of Confederation buttressed. As a result, the nation found unity in action through the call for the Constitutional Convention - which led to the birth of the United States Constitution.

The Constitutional Convention was convened with the intent of amending the Articles of Confederation, yet it resulted in the conception of the United States Constitution. The Constitutional Convention began slowly due to a lack of delegates, yet it rapidly gained speed and the final draft was submitted by the members of the Constitutional Convention on September 17, 1787. ${ }^{3}$ The basis of the unratified Constitution was shaped by a small group of Federalists following a set of "framers' goals" - federalism, voting, a unified militia, and liberty - as well as structural advice influenced by philosophers, the nation's founding independence documents, and state constitutions such as those from Virginia and Massachusetts.

In devising the best mode of governance, the Anti-Federalists were adamant about the preservation of the nation's core value of state sovereignty. The newly created Constitution was widely supported -- 39 of the 41 delegates present signed the final draft of the Constitution -enabling it to be sent to the states for ratification. ${ }^{4}$ The three delegates who declined the draft signage- George Mason, Edmund Randolph, and Elbridge Gerry - were strong Anti-Federalists and rooted their opposition in the lack of law present to protect state sovereignty. ${ }^{5}$ The three men's demand for a bill of rights played a crucial role in the Anti-Federalists' success during debates in state ratification conventions.

Following September 17, 1787, the Constitution was presented to the thirteen states for debate and ratification. With little to no opposition, the first five states ratified. The first state to cause strife in the ratification process was Massachusetts. ${ }^{6}$ Eldridge Gerry ${ }^{7}$, the representative for Massachusetts, was the first to express the fear of the states' and the people's sovereignty being

3 “Founding Fathers," National Constitution Center, accessed October 9, 2018, https://constitutioncenter.org/learn/educational-resources/founding-fathers.

${ }^{4}$ Ibid.

5 "Founding Fathers."

${ }^{6}$ Observing Constitution Day, The U.S. National Archives and Records Administration, 2016, accessed October 9, 2018, https://www.archives.gov/education/lessons/constitutionday/ratification.html.

${ }^{7}$ Center for the Study of the American Constitution UW- Madison, "Elbridge Gerry: To the Massachusetts General Court, 18 October, Massachusetts Centinel, 3 November 1787," Assessments of Individual Delegates, University of Wisconsin-Madison, 2018, accessed October 9, 2018, https://csac.history.wisc.edu/document-collections/the-constitutionalconvention/assessments-of-individual-delegates/. 
in danger, resulting in a formal demand for a bill of rights. With the Massachusetts Ratifying Convention at a standstill between the Federalists and Anti-Federalists, John Hancock was called to the convention in order to reach a compromise to ratify the Constitution. John Hancock's compromise resulted in two major advancements which led to the ratification of the remaining states: the demand for a bill of rights and the creation of recommendatory amendments as a means to seek compromise with the Anti-Federalists. ${ }^{8}$ Within Massachusetts's recommendatory amendments was the foundation of the Tenth Amendment. As explicitly stated in Massachusetts's ratification: "First, That it be explicitly declared that all Powers not expressly delegated by the aforesaid Constitution are reserved to the several States to be by them exercised."9 The demand for a bill of rights and the presence of the Tenth Amendment was seen throughout the recommendatory amendments of the remaining seven states.

In response to the recommendatory amendments proposed by the states, James Madison authored the Bill of Rights. Although Madison's response was due to the recommendatory amendments of the states, he was influenced by a variety of sources. Madison's inspiration, other than the states' ratifications and constitutions, started from the Articles of Confederation, the Virginia Declaration of Rights, and the Declaration of Independence.

The Tenth Amendment was, in fact, a close replication of Article II of the Articles of Confederation: "Each state retains its sovereignty, freedom, and independence, and every power, jurisdiction, and right, which is not by this Confederation expressly delegated to the United States, in Congress assembled." that George Mason attempted to impose on the Constitution years later. The Declaration emphasized the protection of individual rights, state sovereignty, the foundation of the Bill of Rights, and, most importantly, the Tenth Amendment. ${ }^{11}$ The themes of safeguarding individual and state sovereignty proposed by the Virginia Declaration of Rights was also woven into the Declaration of Independence. Thus, the Declaration of Independence acted as a tool for James Madison in his conceptualization of the Tenth Amendment as it emphasized the original inspirations of nationhood: a split from an empire that did not ensure the people's life, liberty, or pursuit of happiness.

If it were not for the Anti-Federalists and their fear of losing state sovereignty, there would be no Bill of Rights and, more specifically, no Tenth Amendment. The Anti-Federalists,

${ }^{8}$ Center for the Study of the American Constitution UW- Madison, The Role of John Hancock in the Massachusetts Convention, University of Wisconsin-Madison, 2018, accessed October 9, 2018, https://csac.history.wisc.edu/states-and-ratification/massachusetts/johnhancock/.

${ }^{9}$ United States Department of Bureau of Rolls and Library, Documentary History of the Constitution of the United States of America, 1786-1870 (Washington: Department of State, 1894), under "Common Wealth of Massachusetts," https://books.google.com/books?id=u10PAAAAYAAJ\&printsec=frontcover\& source $=$ gbs_ge_summary_r\&cad $=0 \# \mathrm{v}=$ onepage $\& q \& \mathrm{f}=$ false.

10 The Avalon Project, Articles of Confederation: March 1, 1781, Lillian Goldman Law Library, 2008, accessed October 9, 2018, http://avalon.law.yale.edu/18th_century/artconf.asp.

${ }^{11}$ America's Founding Documents: The Virginia Declaration of Rights, The U.S. National Archives and Records Administration, 2016, accessed October 9, 2018, https://www.archives.gov/founding-docs/virginia-declaration-of-rights. 
although often viewed as the villain in the creation of the Constitution, were the heroes in our Country's struggle to protect the liberties of the people and states. Paul Finkelman, a distinguished American historian, stated that the debate on the Bill of Rights was "drawn by the Anti-Federalists' fear that the new Constitution would lead to tyranny and the Federalists' equally compelling fear that a less-strong constitution would lead to anarchy." 12 As such, the Anti-Federalists in all of their proposed amendments demanded the preservation of certain aspects of the Articles of Confederation they believed to be crucial in safeguarding individual and state liberties. Without changing the basis of the Constitution or the Bill of Rights, the Tenth Amendment is "rightly understood as a Federalist effort at compromise designed to accommodate Antifederalist concerns that a strong national government might threaten individual liberties."13 The supporting fear originated from the prospect that "we had just concluded a war in defense of those rights and insisted that they forever be guaranteed."14 Although the Federalists framed the Constitution, the Anti-Federalists' vigorous debate and relentless drive forced the Federalists into a compromise that was an integral tool for the nation in preserving the liberties and rights of the people and the states.

Although the Tenth Amendment made its debut in the Supreme Court in 1819, it was only in reference and not in favor of preserving the liberties and rights of the people and states. The evolution of the Tenth Amendment's interpretation spans from 1819 to the present day, yet is only implemented in the Supreme Court in two short periods: the interwar period and the past 42 years.

Originally the Tenth Amendment was used and interpreted in the same manner as its origins - a compromise intended for ratification. The Tenth Amendment was ratified in 1791, yet it did not appear in the Supreme Court until 1819. In McCulloch v. Maryland of 1819, Maryland demonstrated the common belief surrounding the value of the Tenth Amendment. ${ }^{15}$ Maryland's attorneys stated that "the $10^{\text {th }}$ amendment to the constitution is merely declaratory; that it was adopted ex abundanti cautela; and that with it, nothing more is reserved than would have been reserved without it." 16 To further voice their opposition of the Tenth Amendment as a form of refute to their argument, "Maryland opposed the argument "that... the powers which are expressly granted to the national government in the constitution' should be 'enlarged to an

${ }^{12}$ Gary McDowell, "Review of The Bill of Rights: Government Proscribed," William and Mary Quarterly 56, no. 2 (1999): 462, accessed October 9, 2018, https://www.jstor.org/stable/2674144.

${ }^{13}$ William Nelson, "Reason and Compromise in the Establishment of the Federal Constitution, 1787-1801," The William and Mary Quarterly 44, no. 3 (1987): 475, accessed October 9, 2018, https://www.jstor.org/stable/1939766.

${ }^{14}$ Lee Reese, "George Mason the True Father of thet Bill of Rights in the U.S. Constitution." Education 112, no. 1 (1991): 36, accessed October 9, 2018, https://search.ebscohost.com/login.aspx?direct=true\&db=aph\&AN=9112160966\&site=eh ost-live.

${ }^{15}$ McCulloch v. Maryland, 17 U.S. 316 (1819).

16 John R. Vile, "Truism, Tautology or Vital Principle - The Tenth Amendment since United States v. Darby," Cumberland Law Review 27, no. 2 (1997): 452, https://heinonline.org/HOL/P?h=hein.journals/cumlr27\&i=462. 
indefinite extent, by the sweeping clause." ${ }^{\prime 17}$ Only five years later, the Tenth Amendment was referred to in the ruling of Gibbons $v$. Ogden ${ }^{18}$, yet any authority it had the capability of holding was dismissed. Chief Justice Marshall indirectly discredited what little power the Tenth Amendment held as he broadened federal authority through expanding their regulation of interstate trade and the definition of commerce.

As the United States entered the interwar period, the Tenth Amendment experienced a transition in its judicial interpretation and application. The Tenth Amendment's first shift from the framers' intent appeared in Hammer v. Dagenhart, 1918. This case introduced the phrase "explicitly" into the Tenth Amendment, born from the interpretation of Judge Day, speaker for the Court majority. The case was between the state of North Carolina and the father of a boy who took part in child labor. The state employed "the Keating-Owen Child Labor Act which prohibited the interstate shipment of the goods produced by child labor." ${ }^{19}$ However, the Supreme Court decided that the congressional act violated the Commerce Clause and the Tenth Amendment, as the regulation of the production of goods was a power reserved to the states. ${ }^{20}$

During the interwar period, the federal government, especially in its use of presidential power, was expanding. The expansion stemmed from Franklin D. Roosevelt's unprecedented number of presidential terms and his implementation of the New Deal - a set of sweeping government programs that encompassed social and economic reform. Therefore, in addition to Hammer v. Dagenhart, the Supreme Court accepted cases that warranted the enforcement of federalism, specifically the federal government's encroachment into states' sovereignty. Thus, another major case -- Schechter Corp. v. United States of 1935 -- took place in the interwar period. The case questioned whether "Congress unconstitutionally delegate(d) legislative power to the President by giving him power to regulate certain industries without also providing guiding standards." 21 In response, the Supreme Court, under Chief Justice Hughes, unanimously decided that 'the Act was 'without precedent' and was an unconstitutional delegation of legislative authority. The president cannot be allowed to have unbridled control to make whatever laws he believes to be necessary to achieve a certain goal." 22 Three years after Schechter Corp. v. United States, Congress enacted the Fair Labor Act of 1938 (FLSA), an act that reflected the new political atmosphere. In short, the New Deal dictated the political atmosphere of the early to late 1930s. The FSLA, a result of the New Deal, "epitomize(d) the revised boundaries of national and state government authority", via an "altered constitutional meaning of "interstate commerce." 23 After Schechter Corp. v. United States, the political atmosphere that supported greater national power was reflected in the following forty years.

17 Ibid.

${ }^{18}$ Gibbons v. Ogden, 22 U.S. 1 (1824).

19 “Hammer v. Dagenhart,” Oyez, accessed November 9, 2018, https://www.oyez.org/cases/1900-1940/247us25.

${ }^{20}$ Hammer v. Dagenhart, 247 U.S. 251 (1918).

21 “A. L. A. Schechter Poultry Corporation v. United States,” Oyez, accessed November 9, 2018, https://www.oyez.org/cases/1900-1940/295us495.

${ }^{22}$ Ibid.

${ }^{23}$ Suzanne B. Mettler, "Federalism, Gender, \& the Fair Labor Standards Act of 1938," Polity 26, no. 4 (1994): 636, https://www.jstor.org/stable/3235098. 
One major case entertained the Tenth Amendment during those forty years, however, the court reflected the original beliefs regarding the Amendment when the political atmosphere was ripe for a strong national government. In 1940, the case of United States v. Darby was brought to court where Justice Stone wrote his famous decision "reversing key Tenth Amendment precedents - most notably Hammer v. Dagenhart - and, at least for a time, 'reduc[ing] the [Tenth] amendment to rubble.' In upholding the minimum wage and maximum hours provisions of the Fair Labor Standards Act of 1938."24 After Justice Stone "proceeded to cite and to demolish [the Tenth Amendment]"25, the Amendment took its place in the back of the court and did not emerge again until 1976.

In the 1970s, the social and political atmosphere of the United States marked a period of unrest. The Tenth Amendment resurfaced in the Supreme Court in the Seventies, an era full of historical moments that put stress on the power and jurisdiction of the federal government. The historical moments, more or less, reflected poorly on the federal government, and in return pushed the trust of the hoi polloi towards the state governments. The events of the 1970s included, but were not limited to Watergate, the Equal Rights Amendment, the Vietnam War, and environmental issues. The National League of Cities v. Usery ${ }^{26}$ case of 1976, in the height of political turbulence, was the trigger case that returned the Tenth Amendment to the forefront of the Supreme Court playbook for the following decades. Following Usery were five major Supreme Court cases that all followed similar interpretations of the Tenth Amendment, an amendment used to restrict the federal government's power over state governments, especially in the jurisdiction of interstate commerce. From 1992 to 2011, the United States took on New York $^{27}$, Lopez $^{28}$, Printz ${ }^{29}$, Morrison $^{30}$, and Bond ${ }^{31}$ in the Supreme Court. All of the cases resulted in the United States losing to the opposing party via the application of the Tenth Amendment in the protection of individual and state's rights.

Although the Tenth Amendment holds great importance in the Supreme Court today, the Amendment is still under scrutiny. Many, inside and outside of the Court, see the Tenth Amendment as a truism. Since the history of the Tenth Amendment is most closely tied to the result of a compromise, the Amendment is easily labeled as a means to quell the fears of the Anti-Federalists. The two most prominent Supreme Court Justices to voice their opinion on not only the significance, but also the existence, of the Tenth Amendment were Justice Stone and Justice O'Connor.

Justice Stone explained "that the amendment added nothing new of substance to the Constitution but was merely 'declaratory' of a pre-existing state-national relationship", and more so that "the amendment was designed merely "to allay fears that the new national government might seek to exercise powers not granted, and that the states might not be able to exercise fully

\footnotetext{
${ }^{24}$ Vile, "Truism, Tautology or Vital Principle - The Tenth Amendment since United States v. Darby," 458.

${ }^{25}$ Ibid.

${ }^{26}$ National League of Cities v. Usery, 426 U.S. 833 (1976).

${ }^{27}$ New York v. United States, 505 U.S. 144 (1992).

${ }^{28}$ United States v. Lopez, 514 U.S. 549 (1995).

${ }^{29}$ Prints v. United States, 521 U.S. 898 (1997).

${ }^{30}$ United States v. Morrison, 529 U.S. 598 (2000).

${ }^{31}$ Bond v. United States, 564 U.S. 211 (2011).
} 
their reserved powers." ${ }^{232}$ Here Justice Stone's explanation reflects that of Marshall's in McCulloch v. Maryland. Justice O'Connor further stood to demonstrate a parallel view in the modern Court. ${ }^{33}$ Justice O'Connor "customarily refer[ed] to the 'spirit' of the Tenth Amendment, almost as though she believ[ed] that the amendment itself [was] dead." 34 The two Supreme Court Justices were not against the principles that stood behind the Tenth Amendment, instead they viewed the existence of the Tenth Amendment as unnecessary, as they believed that the principle of federalism was already laid out and protected in the Constitution.

In refute, the extensive use of the Tenth Amendment to ensure the security of both state and individual rights has disproven the perspective that the Amendment is only a declaratory statement or a truism. Although it is true that the Tenth Amendment could be viewed as a tautology, it would not be a wholesome evaluation. Without the direct declaration of the Tenth Amendment, the principles it holds -- although implied from the enumerated power -- would not be explicitly reserved for the people and the states. More specifically, the rights that the Tenth Amendment reserves provides the judicial system with solid means to build an argument to protect individuals and states against the expansion of the federal government. In short, "the Tenth Amendment, in fact, is the very essence of the Constitution: its purpose is to ensure that the federal government is truly a government of enumerated powers. It protects not only the powers of the states in our federal system but also the rights of individuals." 35 The Tenth Amendment evolved from a piece of text constructed to appease the fears of the Anti-Federalists to an amendment that is "understood as providing a rule of interpretation for the Constitution as a whole, with special reference to the scope of federal powers." 36

The public involvement with issues concerning the expansion of the federal government indirectly played a significant role in the development of the Tenth Amendment. However, the American public's interpretation of the Tenth Amendment remains in its developmental stages. Across multiple well accredited and politically biased news sources, the Tenth Amendment is still seen as an anomaly. For instance, The Atlantic published a piece in 2011 titled "U.S. v. Bond: Reexamining the Mysterious $10^{\text {th }}$ Amendment." 37 Another example, sourced from Fox News, was titled "The Tenth Amendment: Out of the shadows and into the spotlight." "I8 In more recent news, the Tenth Amendment has made an appearance as a topic of discussion beyond the walls of the Supreme Court; it has made its way onto the floor of Congress. As recently as

${ }^{32}$ Vile, "Truism, Tautology or Vital Principle - The Tenth Amendment since United States v. Darby," 461.

${ }^{33}$ Ibid., 459.

${ }^{34}$ Ibid.

${ }^{35}$ David N. Mayer, "Justice Clarence Thomas and the Supreme Court's Rediscovery of the Tenth Amendment," Capital University Law Review 25, no. 2 (1996): 343,

${ }^{36}$ Ibid. https://heinonline.org/HOL/P?h=hein.journals/capulr25\&i=363.

${ }^{37}$ Garret Epps, "U.S. v. Bond: Reexamining the Mysterious $10^{\text {th }}$ Amendment," The Atlantic, February 18, 2011, https://www.theatlantic.com/national/archive/2011/02/us-v-bondreexamining-the-mysterious-10th-amendment/71436/.

${ }^{38}$ Steve Kurtz, "The Tenth Amendment: Out of the shadows and into the spotlight," Fox News, January 31, 2018, https://www.foxnews.com/us/the-tenth-amendment-out-of-theshadows-and-into-the-spotlight. 
October of 2018, The National Law Review published an article titled "What you Need to Know About the Strengthening the Tenth Amendment Through Entrusting States (STATES) Act."39 With a new bill regarding the Tenth Amendment and a quickly escalating political atmosphere that is resistant to the expansion of the federal government, the Tenth Amendment is in the midst of a new era of development.

Just as it was during the time of the Constitutional Convention and the years preceding ratification, human nature continues to mirror the ideas of Hobbes. At their core, humans have the innate need to fill all voids with whatever power they can summon. It is because of this that the Anti-Federalists believed that the ideal state of dual federalism would become imbalanced without stated law, thus favoring the federal government and neglecting state sovereignty. When writing the Federalist Papers, Alexander Hamilton did not anticipate or care to envision the ruthless greed for power that humans embody. As so, he and the other founders took what they knew of the Articles of Confederation, a document that lent too much power to the states, and constructed a Constitution that leaned in the other direction. Therefore, with little room to combat the strength of the central government, the Anti-Federalists secured the Tenth Amendment.

Without a doubt, the numerous cases in which the Tenth Amendment was necessary to justify the protection of either individual or state rights exemplified the exact fears of the AntiFederalists. In all of those cases, the Tenth Amendment acted just as it was intended - to protect the people, the states, and their individual sovereignty from the federal government. The Tenth Amendment has significantly impacted the U.S. political system, evolving from a mere compromise to a legitimate form of legislation central to maintaining a balanced form of federalism.

${ }^{39}$ Gene Markin, "What you Need to Know About the Strengthening the Tenth Amendment Through Entrusting States (STATES) Act," The National Law Review, October 11, 2018, https://www.natlawreview.com/article/what-you-need-to-know-about-strengtheningtenth-amendment-through-entrusting-states. 


\section{Bibliography}

“A. L. A. Schechter Poultry Corporation v. United States.” Oyez. Accessed November 9, 2018. https://www.oyez.org/cases/1900-1940/295us495.

A. L. A. Schechter Poultry Corporation v. United States. 295 U.S. 495 (1935).

“Amendment X: Rights to States or People.” National Constitution Center. Accessed November 1, 2018. https://constitutioncenter.org/interactive-constitution/amendments/amendment-X.

America's Found Documents: The Virginia Declaration of Rights. The U.S. National Archives and Records Administration. 2016. Accessed October 9, 2018. https://www.archives.gov/founding-docs/virginia-declaration-of-rights.

Bond v. United States. 564 U.S. 211 (2011).

Center for the Study of the American Constitution UW- Madison. "Elbridge Gerry: To the Massachusetts General Court, 18 October, Massachusetts Centinel, 3 November 1787." Assessments of Individual Delegates. University of Wisconsin-Madison. 2018. Accessed October 9, 2018. https://csac.history.wisc.edu/document-collections/the-constitutionalconvention/assessments-of-individual-delegates/.

Center for the Study of the American Constitution UW- Madison. The Role of John Hancock in the Massachusetts Convention. University of Wisconsin-Madison. 2018. Accessed October 9, 2018. https://csac.history.wisc.edu/states-and-ratification/massachusetts/johnhancock/.

Ching, Anthony B. "Travelling Down the Unsteady Path: United States v. Lopez, New York v. United States and the Tenth Amendment." Loyola of Los Angeles Law Review 29, no. 1 (November 1995): 99-144. https://heinonline.org/HOL/P?h=hein.journals/lla29\&i=127.

Epps, Garrett. “U.S. v. Bond: Reexamining the Mysterious $10^{\text {th }}$ Amendment." The Atlantic, February 18, 2011. https://www.theatlantic.com/national/archive/2011/02/us-v-bond reexamining-the-mysterious-10th-amendment/71436/.

“Founding Fathers." National Constitution Center. Accessed October 9, 2018. https://constitutioncenter.org/learn/educational-resources/founding-fathers.

Gibbons v. Ogden. 22 U.S. 1 (1824).

Hamilton, Alexander, John Jay, and James Madison. The Federalist Papers. Constitution Society, 2009. Library of Congress eBook.

Hammer v. Dagenhart. 247 U.S. 251 (1918).

“Hammer v. Dagenhart.” Oyez. Accessed November 9, 2018. https://www.oyez.org/cases/1900 1940/247us25.

Kurtz, Steve. "The Tenth Amendment: Out of the shadows and into the spotlight." Fox News, January 31, 2018. https://www.foxnews.com/us/the-tenth-amendment-out-of-the shadows-and-into-the-spotlight. 
Markin, Gene. "What you Need to Know About the Strengthening the Tenth Amendment Through Entrusting States (STATES) Act." The National Law Review, October 11, 2018. https://www.natlawreview.com/article/what-you-need-to-know-about-strengthening tenth-amendment-through-entrusting-states.

Mayer, David N. "Justice Clarence Thomas and the Supreme Court's Rediscovery of the Tenth Amendment." Capital University Law Review 25, no. 2 (1996): 339-424. https://heinonline.org/HOL/P?h=hein.journals/capulr25\&i=363.

McCulloch v. Maryland. 17 U.S. 316 (1819).

McDowell, Gary. "Review of The Bill of Rights: Government Proscribed." William and Mary Quarterly 56. no. 2 (1999): 461-463. https://www.jstor.org/stable/2674144.

Mettler, Suzanne B. "Federalism, Gender, \& the Fair Labor Standards Act of 1938." Polity 26, no. 4 (1994): 635-54. https://www.jstor.org/stable/3235098.

National League of Cities v. Usery. 426 U.S. 833 (1976).

Nelson, William "Reason and Compromise in the Establishment of the Federal Constitution, 1787-1801." The William and Mary Quarterly 44, no. 3 (1987): 458-484. https://www.jstor.org/stable/1939766.

New York v. United States. 505 U.S. 144 (1992).

Observing Constitution Day. The U.S. National Archives and Records Administration. 2016. Accessed October 9, 2018. https://www.archives.gov/education/lessons/constitutionday/ratification.html.

Prints v. United States. 521 U.S. 898 (1997).

Reese, Lee. "George Mason the True Father of the Bill of Rights in the U.S. Constitution." Education 112, no. 1 (1991): 34-37.

https://search.ebscohost.com/login.aspx?direct=true $\& d b=a p h \& A N=9112160966 \&$ site $=e h$ ost-live.

Soifer, Aviam. "Truisms That Never Will Be True: The Tenth Amendment and the Spending Power." University of Colorado Law Review 57, no. 5 (Fall 1986): 793-834. https://heinonline.org/HOL/P?h=hein.journals/capulr25\&i=363.

The Avalon Project. Articles of Confederation: March 1, 1781. Lillian Goldman Law Library. 2008. Accessed October 9, 2018. http://avalon.law.yale.edu/18th_century/artconf.asp.

U.S. Constitution, amend. 10.

United States v. Darby. 312 U.S. 100 (1941).

United States Department of Bureau of Rolls and Library. Documentary History of the Constitution of the United States of America. 1786-1870 Washington: Department of State, 1894. https://books.google.com/books?id=u10PAAAAYAAJ\&printsec=frontcover\&source=gb s_ge_summary_r\&cad=0\#v=onepage \&q\&f=false. 
United States v. Lopez. 514 U.S. 549 (1995).

United States v. Morrison. 529 U.S. 598 (2000).

Vile, John R. "Truism, Tautology or Vital Principle - The Tenth Amendment since United States v. Darby." Cumberland Law Review 27, no. 2 (1997): 445-532. https://heinonline.org/HOL/P?h=hein.journals/cumlr27\&i=462. 